\title{
67. CHEMICAL AND BITUMINOLOGICAL STUDIES FROM HOLES 434, 434A, AND 434B, DEEP SEA DRILLING PROJECT
}

\author{
A. A. Geodekyan, T. G. Chernova, V. Y. Trotsyuk, Z. I. Verkhovskaya, and A. P. Bokovoi \\ P. P. Shirshov Institute of Oceanology, USSR Academy of Sciences, Moscow, U.S.S.R.
}

\begin{abstract}
Geochemical investigation of 18 samples of sediments from Site 434 involved determining the content of organic carbon, of bitumoid $A$ (The chloroform $A_{\text {chl }}$ and alcohol-benzene $A_{\text {alb }}$ extracts) and its various fractions, and of individual hydrocarbons as well as the structural group composition of resins. We identified certain samples that differed sharply from the rest by their increased bitumen content and relatively low molecular hydrocarbons and by the fact that their resinous components were more neutral and aliphatic in composition. The distribution of bitumoid and its components seems to reflect migration processes in operation during the early stages of the transformation of organic matter.
\end{abstract}

\section{INTRODUCTION}

Interest in the geochemical investigation of organic matter stems from the existence of alternative opinions on the formation of oil and gas beneath deep-water oceanic trenches. Some researchers (Hedberg, 1970) invoked the concept of plate tectonics to infer a high oil potential in sedimentary basins confined to the structures of deep-water trenches. Others (Geodekyan et al., 1975 ) suggest that catagenetic transformation of organic matter in deep-water trenches accounts for most hydrocarbon gas formation. Thus it appears important to analyze soluble components - or bitumoids - of organic matter to determine the direction of their subsequent thermal destruction.

\section{PROCEDURE}

We analyzed 18 samples of sediments from Site 434 at depth intervals from 5 to 506 meters. The procedure is diagrammed in Figure 1. Details have been described earlier (Geodekyan et al., 1978) except for two operations: (1) removal of elemental sulfur from chloroform extract (butimen $\mathrm{A}_{\mathrm{chl}}$ ) and (2) removal of mineral salts from the alcohol-benzene extract $\left(\mathrm{A}_{\mathrm{alb}}\right)$.

\section{Removal of Sulfur from $A_{\text {chl }}$}

Bitumoid is dissolved in a small amount of chloroform (2-5 ml, according to weight), and 1 to 2 drops of metallic mercury are added. The solution is shaken for 1 to $2 \mathrm{~min}$. and the deposited mercuric sulfide filtered through dense paper. The operation is continued until the black deposit of mercuric sulfide no longer forms. The extracts are dried in a vacuum thermostat at $40^{\circ}$ to $50^{\circ} \mathrm{C}$.

\section{Removal of Salts from $\mathbf{A}_{\text {alb }}$}

After drying, the alcohol-benzene extract is treated with hot benzene or with chloroform, in which mineral salts are insoluble. The solution is then filtered through paper, which retains the mineral salts and some of the undissolved components. The filter is then washed with hot distilled water until a negative reaction to chlorine ion is obtained (test for $\mathrm{AgNO}_{3}$ ). Next the contents are dried in a vacuum thermostat and dissolved with alcohol-benzene $(1: 2)$. The resulting bitumoid mixture is transferred to a weight-calibrated glass and then dried in a vacuum thermostat at $40^{\circ}$ to $50^{\circ} \mathrm{C}$. This decontamination procedure produces bitumoid with an ash content of 1 to 2 per cent or, occasionally, ash-free.

\section{Results and Preliminary Discussion}

Organic carbon content is within 0.3 to 1.0 per cent; the maximum concentration occurs in the two uppermost samples, at 5.2 and 7.0 meters. No trend in organic carbon content was observed, as shown in Figure 2. Compared to the statistical mean of earlier oceanic trench sediments, such as 0.4 per cent (Trotsyuk, 1976), organic carbon content in the present samples was 1.5 times as high; the reason obviously lies in the specific genetic composition of organic matter, which is principally diatomaceous.

Variation in $\mathrm{A}_{\text {chl }}$ content is considerable (0.006-0.177 per cent). The majority of samples reveal low bitumoid coefficients $\left(\beta_{\text {chl }}\right)^{1}-$ from 1.08 to 3.28 per cent. Samples from 169.0 and 226.3 meters have high $\beta_{\text {chl }}$ values (5.0 and 7.3 per cent, respectively), and a sample from 36.0 meters has an extremely high value ( 26.42 per cent).

$\mathrm{A}_{\text {alb }}$ content in the majority of samples exceeds that of $\mathrm{A}_{\text {chl }}$ by 1.3 to 1.5 times. However, samples characterized by high and very high values of the $\beta_{\text {chl }}$ parameter reveal the opposite picture: $A_{c h l}$ turns out to be more abundant than $\mathrm{A}_{\text {alb }}$ by 2 to 6 times.

$$
{ }^{1} \beta_{\text {chl }}=\frac{\% \mathrm{~A}_{\text {ch } 1}}{\% C_{\text {org }}} \times 100 .
$$




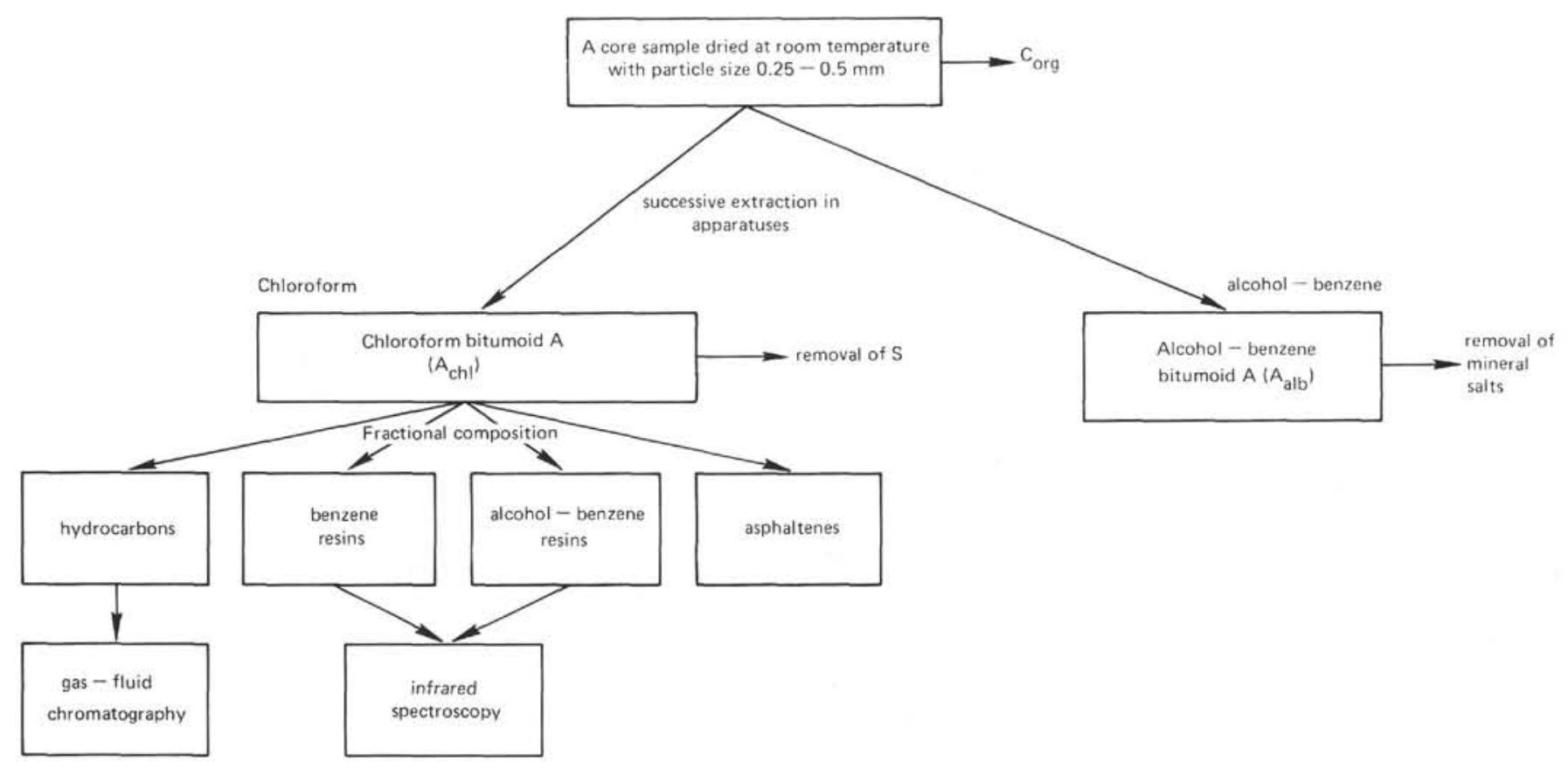

Figure 1. Scheme of analysis of organic matter.

The extracted substance is fairly acidic, owing to a high asphaltene and resin content (87-97 per cent). Such a bitumen composition is typical of weakly altered organic matter unaffected by thermal destruction.

Also noteworthy is the relatively high methane-naphthene hydrocarbon content (mean value 0.0055 per cent), attaining in some samples 0.02 and even 0.09 per cent.

\section{Structural Group Composition of Various Fractions of $\mathbf{A}_{\text {chl }}$}

Analysis of the composition of the hydrocarbon fraction identified $n$-alkanes with the number of carbon atoms from 15 to 35 , as well as the isoprenoids pristane and phytane (Table 1). The hydrocarbon composition of the majority of sediments studied is characterized by high amounts of relatively high molecular components: the sum of $\mathrm{C}_{29}$ to $\mathrm{C}_{35}$ hydrocarbons accounts for over 50 per cent. Maximum abundances in the $\mathrm{C}_{27}, \mathrm{C}_{29}$, and $\mathrm{C}_{31}$ hydrocarbons have been clearly recorded in nearly all samples. Carbon preference index (CPI) varies from 0.82 to 1.92 , the dominance of the odd over the even molecules being confined mainly to the high molecular hydrocarbons. Such a hydrocarbon composition is likely to be due to an admixture of terrigenous material.

Sediments characterized by high amounts of bitumoid have specific distribution of individual component concentrations in the hydrocarbon fraction. Samples from $36.0,169.3$, and 226.2 meters were found to have high amounts of relatively low molecular hydrocarbon components. Thus at the 226.2-meter depth the sum of $\mathrm{C}_{16}$ to $\mathrm{C}_{24}$ hydrocarbons is equal to 73.05 per cent, and hydrocarbons heavier than $C_{32}$ are absent. CPI in these samples is at its lowermost (1.03-0.83). Underlying cores reveal a sharp reduction in the proportion of low molecular hydrocarbons $\left(\mathrm{C}_{16}-\mathrm{C}_{24}=40.9\right.$ per cent $)$ and $\mathrm{CPI}$ as high as 1.57 .
Some specimens revealed the presence of pristane and phytane, the latter being predominant.

The resinous substances isolated from sediments high in bitumoids and hydrocarbons likewise exhibit structural characteristics slightly different from those of other samples. Specifically, they show more paraffin and naphthene structures and a significant decline (3-10 times) in the proportion of aromatic fragments and carboxyl-carbonyl functional groups. Consequently, resins in these samples are distinguished by a more neutral and aliphatic composition.

\section{CONCLUSIONS}

The distribution of geochemical characteristics points to a predominantly syngenetic type of organic matter and to the presence of para-autochthonous bitumoid in some of the samples. This permits us to assume the presence of redistribution and migration processes in the case of the most mobile (bitumoidal) components of organic matter, particularly of some of their fractions within the confines of individual sedimentary horizons.

Enrichment of organic matter in some horizons with para-autochthomous bitumoid is confined to interlayers containing granulometrically coarse aleurolitic-sandy material. Probably these horizons are the "reservoirs" of the mobile components of organic matter (para-autochthonous bitumen).

Under the conditions of rapid compaction of sediments characteristic for trench sections (due to a combined effect of geostatic pressure and geodynamic compression) there occurs an active segregation of easily migrating organic matter components into overlying beds. Obviously a significant portion of them, together with an ascending flow of porous fluids and natural extraction agents, ultimately returns to the hydrosphere.

Thus the tendency of processes involving transformation of organic matter in deep-water trenches proceeds 


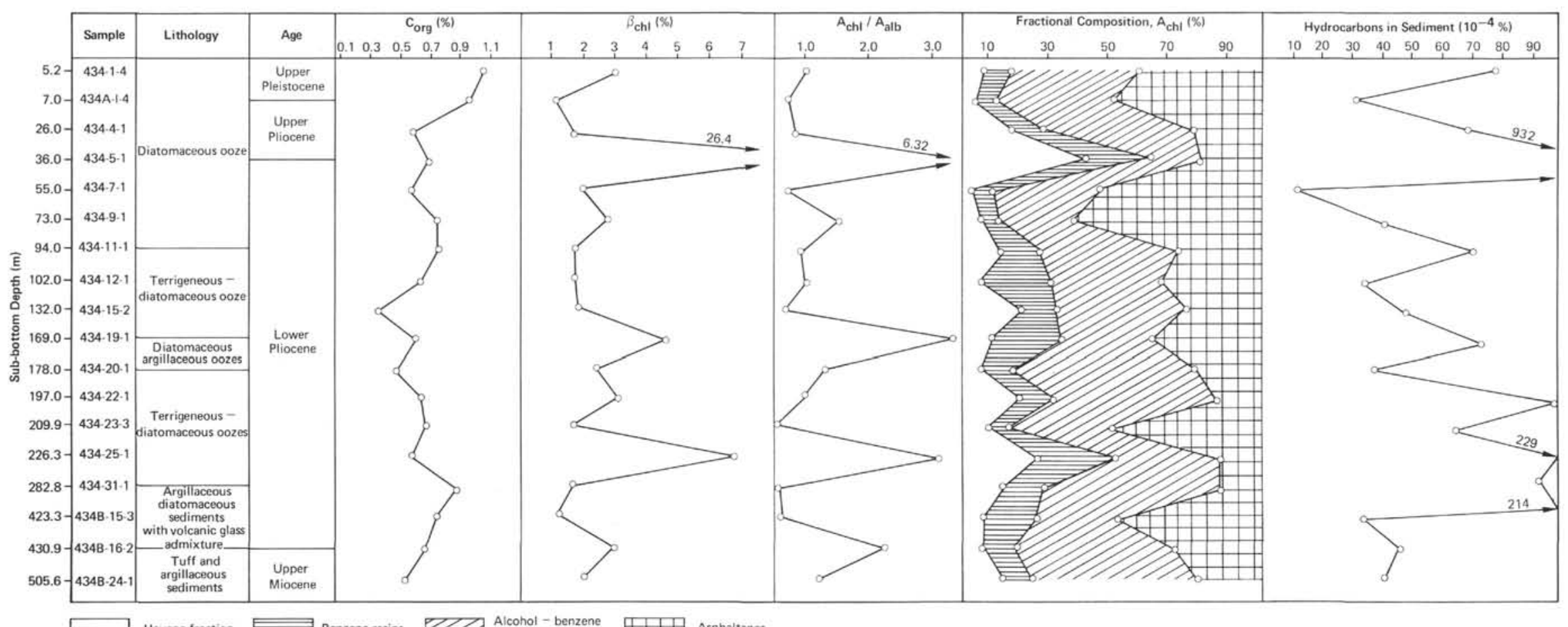

Figure 2. Bituminological characteristic of organic matter. 
TABLE 1

Composition of Paraffin Hydrocarbons (ratio in \%)

\begin{tabular}{|c|c|c|c|c|c|c|c|c|c|c|c|c|c|}
\hline Sample & $\mathrm{C}_{16}$ & $\mathrm{C}_{17}$ & $\mathrm{C}_{18}$ & $\mathrm{C}_{19}$ & $\mathrm{C}_{20}$ & $\mathrm{C}_{21}$ & $\mathrm{C}_{22}$ & $\mathrm{C}_{23}$ & $\mathrm{C}_{24}$ & $\mathrm{C}_{25}$ & $\mathrm{C}_{26}$ & $\mathrm{C}_{27}$ & $\mathrm{C}_{28}$ \\
\hline $434-1-4$ & & & & & 1.16 & 2.88 & 4.05 & 5.78 & 5.78 & 9.25 & 7.52 & 13.87 & 6.94 \\
\hline $\begin{array}{l}434 \mathrm{~A}-1-4 \\
434-4-4\end{array}$ & & & 5.19 & 5.19 & 7.49 & 7.49 & 6.34 & 7.95 & 12.10 & 10.38 & 6.57 & 7.95 & 4.15 \\
\hline $\begin{array}{l}434-5-1 \mathrm{a} \\
434-9-1\end{array}$ & 6.28 & 6.01 & 1.91 & 5.74 & 8.20 & 3.55 & 3.55 & 7.92 & 4.10 & 5.46 & 2.45 & 5.46 & 7.10 \\
\hline $\begin{array}{l}434-11-2 \\
434-12-1\end{array}$ & & & 1.60 & 2.57 & 3.21 & 4.17 & 5.13 & 6.73 & 6.09 & 8.97 & 7.69 & 12.18 & 6.09 \\
\hline $\begin{array}{l}434-19-1 \\
434-20-1\end{array}$ & 1.43 & 3.33 & 1.90 & 2.86 & 4.76 & 4.76 & 7.14 & 9.52 & 8.10 & 10.48 & 12.86 & 7.62 & 11.91 \\
\hline $\left.\begin{array}{l}434-22-1 \\
434-23-3\end{array}\right\}$ & & 0.44 & 1.32 & 2.19 & 3.83 & 5.91 & 6.68 & 9.20 & 8.21 & 9.64 & 8.65 & 10.40 & 6.68 \\
\hline $\begin{array}{l}434-25-1^{\mathrm{b}} \\
434-31-1\end{array}$ & 21.36 & $\begin{array}{r}12.74 \\
3.03\end{array}$ & $\begin{array}{l}8.98 \\
8.42\end{array}$ & $\begin{array}{l}5.56 \\
3.37\end{array}$ & $\begin{array}{l}4.67 \\
3.70\end{array}$ & $\begin{array}{l}4.85 \\
4.71\end{array}$ & $\begin{array}{l}5.03 \\
5.56\end{array}$ & $\begin{array}{l}4.67 \\
6.73\end{array}$ & $\begin{array}{l}3.23 \\
5.39\end{array}$ & $\begin{array}{l}2.33 \\
6.90\end{array}$ & $\begin{array}{l}1.62 \\
5.39\end{array}$ & $\begin{array}{r}2.51 \\
11.27\end{array}$ & $\begin{array}{l}0.90 \\
6.40\end{array}$ \\
\hline $\left.\begin{array}{l}434 \mathrm{~B}-15-3 \\
434 \mathrm{~B}-16-2\end{array}\right\}$ & & & 3.85 & 6.84 & 8.70 & 10.55 & 9.99 & 10.55 & 6.99 & 7.27 & 4.57 & 7.14 & 3.00 \\
\hline $434 \mathrm{~B}-24-1$ & 2.10 & 5.09 & 7.78 & 8.08 & 7.19 & 9.88 & 11.68 & 10.78 & 6.29 & 4.79 & 2.40 & 3.20 & 1.50 \\
\hline
\end{tabular}

TABLE 1 - Continued

\begin{tabular}{|c|c|c|c|c|c|c|c|c|c|c|c|c|}
\hline Sample & $\mathrm{C}_{29}$ & $\mathrm{C}_{30}$ & $\mathrm{C}_{31}$ & $\mathrm{C}_{32}$ & $\mathrm{C}_{33}$ & $\mathrm{C}_{34}$ & $\mathrm{C}_{35}$ & $\begin{array}{l}\text { Pris- } \\
\text { tane }\end{array}$ & $\begin{array}{l}\text { Phy- } \\
\text { tane }\end{array}$ & $\frac{\text { Pristane }}{\text { Phytane }}$ & $\begin{array}{c}\Sigma \mathrm{C}_{16^{-}} \\
\mathrm{C}_{24}\end{array}$ & $\frac{\text { Odd }}{\text { Even }}$ \\
\hline $434-1-4$ & 15.03 & 5.78 & 12.72 & 2.88 & 4.05 & 2.31 & & & & & 19.65 & 1.75 \\
\hline $\left.\begin{array}{l}434 \mathrm{~A}-1-4 \\
434-4-4\end{array}\right\}$ & 7.43 & 2.42 & 5.36 & 2.25 & 1.73 & $\mathrm{tr}$ & & & & & 51.75 & 1.15 \\
\hline $\begin{array}{l}434-5-1^{a} \\
434-9-1\end{array}$ & 5.19 & 5.74 & 3.28 & 2.73 & 5.19 & 4.37 & & 2.19 & 3.01 & 0.73 & 47.26 & 1.03 \\
\hline $\left.\begin{array}{l}434-11-2 \\
434-12-1\end{array}\right\}$ & 13.78 & 4.49 & 12.18 & 1.92 & 3.21 & $\operatorname{tr}$ & & & & & 29.50 & 1.76 \\
\hline $\begin{array}{l}434-19-1 \\
434-20-1\end{array}$ & 6.19 & 5.71 & tr & & & & & $\mathrm{tr}$ & 1.43 & & 43.80 & 0.83 \\
\hline $\left.\begin{array}{l}434-22-1 \\
434-23-3\end{array}\right\}$ & 9.86 & 4.16 & 5.15 & 1.21 & 1.53 & 0.66 & 0.77 & 0.88 & 2.63 & 0.34 & 37.78 & 1.33 \\
\hline $\begin{array}{l}434-25-1^{b} \\
434-31-1\end{array}$ & $\begin{array}{r}2.15 \\
13.47\end{array}$ & $\begin{array}{l}0.72 \\
4.04\end{array}$ & $\begin{array}{r}2.15 \\
11.62\end{array}$ & $\begin{array}{c}1.08 \\
\mathrm{sl}\end{array}$ & $\mathrm{tr}$ & & & 5.39 & 5.21 & 1.04 & $\begin{array}{l}73.07 \\
40.91\end{array}$ & $\begin{array}{l}0.82 \\
1.57\end{array}$ \\
\hline $\left.\begin{array}{l}434 \mathrm{~B}-15-3 \\
434 \mathrm{~B}-16-2\end{array}\right\}$ & 7.27 & 1.86 & 5.42 & 0.86 & 1.72 & $\mathrm{tr}$ & & $\mathrm{tr}$ & 3.42 & & 57.47 & 1.43 \\
\hline $434 \mathrm{~B}-24-1$ & 2.99 & 0.90 & 2.39 & $\mathrm{tr}$ & & & & 4.79 & 6.59 & 0.73 & 68.87 & 1.19 \\
\hline
\end{tabular}

This sample also contains 0.55 per cent $\mathrm{iC}_{18}$.

b This sample also contains 1.98 per cent $\mathrm{C}_{15}$ and 2.87 per cent $\mathrm{iC}_{18}$.

along a path unfavorable to further oil-forming processes.

\section{ACKNOWLEDGMENT}

We would like to thank Jean Whelan for her critical reading of the manuscript.

\section{REFERENCES}

Hedberg, H. D., 1970. Continental margins from the viewpoint of the petroleum geologist. Bull. Am. Assoc. Petrol. Geol., 54 (No. 1), 3-43.
Geodekyan, A. A., et al., 1975. Geological-geochemical evaluation of possible oil and gas content of the Bering Sea, the seas of Okhotsk and Japan, the North-Western Pacific and Arctic Ocean. Proceedings of the Ninth World Petroleum Congress, London. pp. 337-346.

Geodekyan, A. A., et al., 1978. Bituminological studies of the samples from Site 379 and laboratory simulation of dispersed organic matter transformation. In Ross, D. A., Neprochnov, Y. P., et al., Init. Repts. DSDP, 42, Pt. 2: Washington (U.S. Govt. Printing Office), 683-696.

Trotsyuk, V. Ja., 1976. Dokl. Akad. Nauk. SSSR., 231 (No. 1), 165-168. 